\title{
EXPERIMENTAL ALCOHOLIC CIRRHOSIS OF THE LIVER *
}

\author{
ARTHUR L. GROVER, M.D. \\ IOWA CITY, IA.
}

Ever since the experimental method has been used in pathology numerous attempts have been made to show the connection between cirrhosis of the liver as often seen in "steady drinkers" and alcohol as the causative factor. In this experimental work alcohol has been used subcutaneously, intravenously, by inhalation, and fed by mouth. Ethyl alcohol has been used by most all, but some have used amyl and methyl alcohol, while others have used mixtures of these, and still others have used various beverages, such as schnapps, brandy and absinthe. Rabbits, guinea-pigs, dogs, rats, mice, hens, cats, ducks and pigeons have been used as experimental animals. Dahlström, ${ }^{1}$ Duchek, ${ }^{2}$ Joffrey and Serveaux ${ }^{3}$ von Baumgarten, ${ }^{4}$ and de Rechter, ${ }^{5}$ were among the first to carry out work along these lines, but with regative results. Ruge, ${ }^{6}$ Magnan, ${ }^{7}$ Kremiansky, ${ }^{8}$ Mairet and Cambermale, ${ }^{9}$ Afanassiew, ${ }^{10}$ v. Kuhlden, ${ }^{11}$ Friedenwald, ${ }^{12}$ d'Amato, ${ }^{13}$ Strass-

\footnotetext{
* Submitted for publication June 11, 1915.

* From the Laboratory of Pathology and Bacteriology, Medical School, State University of Iowa.

1. Dahlström: Cited from Fahr, Note 23.

2. Duchek: Alkohol im tierisher Organismus, Prager Vierteljahrs, 1853.

3. Joffrey and Serveaux: Mensuration de la toxicite vraie de l'alcool, Arch. de méd. expér. et d'anat. path., 1897.

4. v. Baumgarten: Ueber die durch Alkahol hervorzurufenden pathologischhistologischen Veränderungen, Verhandl. d. deutsch. path. Gesellsch., 1907.

5. De Rechter: Bull de l'.Acad. roy. de méd. Belgique, 1892.

6. Ruge, L.: Wirkung des Alkohols auf den tierschen Organismus, Virchows Arch. f. path. Anat., 1870, xlix.

7. Magnan: Alcoolisme aigu, etc., Compt. rend. Acad. d. sc., 1869, p. 825.

8. Kremiansky, J.: Ueber Pachymeningitis interna hemorrhagica bei Menschen und Hunden, Virchows Arch. f. path. Anat., 1868, xlii.

9. Mairet and Cambermale: Compt. rend. Acad. d. sc., 1888, Nos. 10, 11 and 12 .

10. Afanassiew, W. A.: Zur Pathologie des akuten und chronischen Alkoholismus, Beitr. z. path. Anat. u. z. allg. Path., 1890, viii.

11. v. Kuhlden: Cited by Fahr, Note 23.

12. Friedenwald: Pathological Effects of Alcohol on Rabbits, Jour. Am. Med. Assn., 1905, xlv, 780.

13. d'Amato: Ueber experimentelle, vom Magendarmkanal aus hervorgeru fene Veränderungen der leber und über die dabei gefundenen Veränderungen die ubringen Bauchorgane, Virchows Arch. f. path. Anat., 1907, clxxxvii.
} 
nan, ${ }^{14}$ Pupier, ${ }^{15}$ and Bischoff ${ }^{16}$ in their early work at least got only parenchymatous degeneration of the liver cells as a result. Dujardin Beaumetz and Audige ${ }^{17}$ fed hogs with their food, alcohol in the form of wood alcohol, malt spirits, beef spirits, potato spirits and absinthe. This experiment lasted three years, but owing to the large amount of interlobular connective tissue naturally present in these animals it was not a success

Straus and Blocq ${ }^{18}$ fed rabbits ethyl and amyl alcohol by means of a stomach tube and obtained cirrhosis after three months. Pupier ${ }^{15}$ claimed that experimenting with hens he got an interstitial hepatitis with absinthe, hypertrophic cirrhosis with red wine and atrophic cirrhosis with white wine. Afanassiew ${ }^{10}$ gave dogs, rabbits, guinea-pigs. and white rats, by means of a stomach tube, a mixture of ethyl and amyl alcohol, and in some instances obtained a well marked cirrhosis. $\mathrm{He}$ also injected alcohol into the portal vein of dogs with positive results. De Rechter ${ }^{5}$ got similar results. Mertens ${ }^{19}$ obtained cirrhosis in rabbits by keeping them for a long time in an atmosphere containing a'cohol vapor. Joannovics ${ }^{20}$ successfully repeated this experiment but Challand $^{21}$ and Magnan ${ }^{7}$ were unable to do so. Saltykow ${ }^{22}$ injected absolute alcohol in physiological salt solution in the ear vein of rabbits. One animal lived almost two years, receiving in this time eight injections, each containing $2 \frac{1}{2}$ c.c. of absolute alcohol. He found a resultiing cirrhosis that was well marked macroscopically and microscopically.

14. Strassman, F.: Experimentell Untersuchungen zur Lehr. vom. chronischer alkoholismus, Vrtljschr. f. gerichtl. Med., 1888, xlix.

15. Pupier, Z.: Demonstration expérimentale de l'action des boissons dites spiritueuses sur le boie, Compt. rend. Acad. d. sc., 1872, p. 1415.

16. Bischoff: Neue Beitrage zur experimentellen Alkoholforschung mit besonderer Beruchsichtigung der Hertz und Leberveränderungen, Ztschr. f. exper. Path. u. Therap., xi, Part 3, p. 445.

17. Dujardin Beaumetz and Audige: Recherches expérimentales sur la puissances toxique des Alcools, Paris, 1879; Recherches expérimentales sur l'alcoolisme chronique, Paris, 1884.

18. Straus and Blocq: Etude expérimentale sur la cirrhose alcoolique de foie, Arch. de physiol norm. et path, 1887, Series 3, x, 409.

19. Mertens: Lésions anatomiques du foie du lapin au course de l'intoxication chronique par le chloroforme et par l'alcool, Arch. de pharmacod. et de therap., 1896, ii.

20. Joannovics: Recherches expérimentales sur le pathogenie de l'ictere, Mém. couron. Acad. roy. de méd. de Belg., 1903; Ueber Veränderungen der Leber bei Vergiftung mit Karbaminsäuren und kohlens Ammoniak, Arch. de pharmacorl., 1903, xii ; Ueber experimentelle Lebercirrhose, Wein. klin. Wchnschr., 1904, xvii, 25.

21. Challand, T.: Etude expérimentale et clinique sur absinthisme et l'alcoolisme. Thése de Paris, 1871.

22. Saltykow, S.: Beitrag sur Kenntnis der durch Alkohol hervorgerufenen Organveränderungen, Verhandl. d. deutsch. Gesellsch., 1910, xiv; Experimentelle Forschung über die pathologische Anatomie des Alkoholismus chronicus. Zentralbl. f. allg. Path. u. path. Anat., 1911, xxii, No. 19. 
Fahr $^{23}$ repeated this work using 96 per cent. alcohol on two rabbits and two guinea-pigs for a time period of two years and got a beginning cirrhosis in one rabbit. Lissauer ${ }^{24}$ used 50 per cent. alcohol and brandy in the ear vein of rabbits, and after seven months got evidence of cirrhosis. Schafir ${ }^{25}$ reported success with similar experiments. Pogenpohl, ${ }^{26}$ Siegenbeck von Heukelom, ${ }^{27}$ Klopstock, ${ }^{28}$ v. Baumgarten ${ }^{4}$ and Bischoff, ${ }^{16}$ working along the same lines, got merely fat degeneration. Lancereaux ${ }^{29}$ conducted experimental researches for years on cirrhosis of the liver, particularly the type that is seen in France, and as a result he concludes that alcoholic cirrhosis of the liver is the result of substances used in wine, beer, etc., for their preservation, especially potassium bisulphate. He was able to produce typical lesions of "gin-liver" by feeding animals this salt. The other salts of potassium gave negative results. Kyrle and Schopper ${ }^{30}$ used a 50 per cent. solution of absolute ethyl alcohol in equal parts of water and physiological salt solution intravenously, subcutaneously and by mouth on a series of thirty-one rabbits. The experiment extended over a period of from one hour to thirteen weeks. Each animal received alcohol every second to fourth day, in the dosage of 1.8 c.c. of absolute alcohol per kilo. In all cases the liver showed bile stasis, parenchymatous degeneration and fatty change in the liver cells. These changes commenced about the central veins. In seven cases there was necrosis of portions of the lobe and replacement fibrosis. In fourteen cases there was round cell infiltration of the interlobular spaces, and in seven others connective tissue proliferation with bile duct formation. The livers of three of the rabbits showed typical Laennec's cirrhosis. The authors state that degencration only could be shown during the first two weeks of the experiment, but after that time the connective tissue reaction could be observed.

23. Fahr: Zur Frage des chronischen Alkoholismus, Verhandl. d. deutsch. path. Gesellsch., 1909, xiii ; Diskussionbemerkungen, ibid., 1910, xiv ; ibid., 1911, xv; Virchows Arch. f. path. Anat., 1911, ccv.

24. Lissauer: Lebercirrhose bei experimenteller Intoxication, Virchows Arch. f. path. Anat., 1914, ccxvii, Part 1, p. 56.

25. Schafir: Virchows Arch. f. path. Anat., 1913.

26. Pogenpohl: Zur Frage der Veränderungen des Pankreas bei Lebercirrhose, Virchows Arch. f. path. Anat., 1909, cxvi.

27. Van Heukelom Siegenback: Die experimentelle Cirrhosis hepatitis, Beitr. z. path. Anat. u. z. allg. Path., 1896, xx.

28. Klopstock, F.: Alkoholismus und Lebercirrhose, Virchows Arch. f. path. Anat., 1906, clxxxiv; Zur Leber von der Lebercirrhose, Berl. klin. Wchnschr., 1910, Nos. 33 and 34.

29. Lancereaux: Granular Cirrhosis of the Liver, Bull. de l'Acad. re méd., Paris, 1910, 1xxiv

30. Kyrle and Schopper: Virchows Arch. f. path. Anat., 1913, ccxv, Part 2, p. 359. 
In a previous communication $I^{31}$ made a preliminary report of work on experimental cirrhosis. Two of the cases reported were on experimental alcoholic cirrhosis and are as follows:

Experiment 4.-A rabbit was given by mouth daily; except Sunday, before fcerling-time in the morning, 15 c.c. of 34 per cent. alcohol. This was given with a medicine dropper, and after a few administrations no difficulty was found in the rabbit's swallowing it. By this method I endeavored to reproduce as closely as possible the conditions in the steady drinker that are supposed to predispose to cirrhosis of the liver, namely, a repeated ingestion of alcohol in the "whisky proportion" on an empty stomach. This experiment was started Nov. 4, 1912, and the animal killed April 9, 1913, covering a period of slightly orer five months. Necropsy showed a liver small for an animal as large as this one (which at the beginning was a full sized rabbit, and which

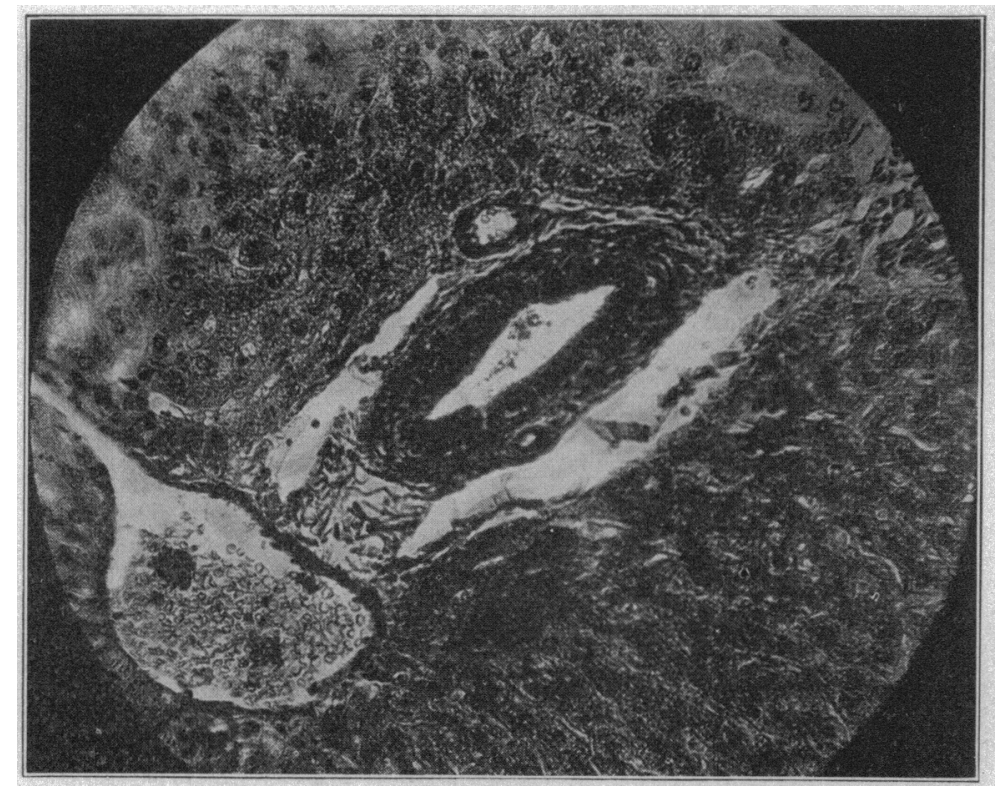

Fig. 1.-Normal rabbit liver showing normal interlobular space with very slight amount of connective tissue between blood vessels and bile ducts.

grew fatter and larger in the meantime, never showing any signs of being sick). The liver markings were extremely prominent and the organ was lighter in color and firmer; there was some slight roughening of the surface. Histologically, sections showed quite a large increase in the interlobular connective tissue in which there were many proliferating bile ducts, the buds and new branches of which stood out very distinctly. In several places it was evident that these were trying to penetrate the periphery of the lobules. The blood ressels were not particularly noticeable. The connective tissue seemed to be proliferating from the preexisting connective tissue in the interlobular

31. Grover, A. L.: Experimental Cirrhosis of the Liver, Jour. Am. Med. Assn.. 1913, 1xi, 458; The Question of Spontaneous Cirrhosis of the Liver in Rabbits and Other Laboratory Animals, Jour. Am. Med. Assn., 1915, 1xiv, 1487. 


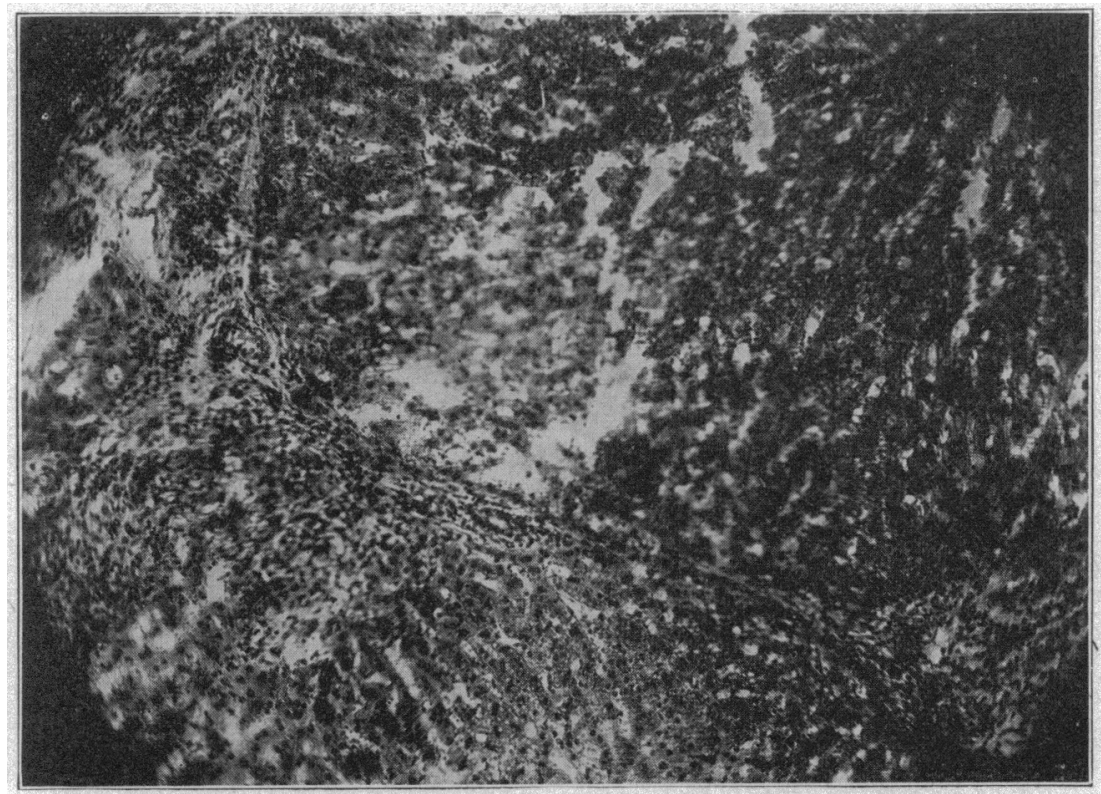

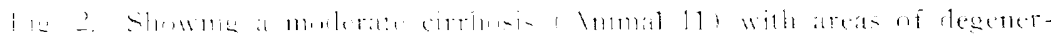

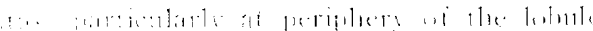

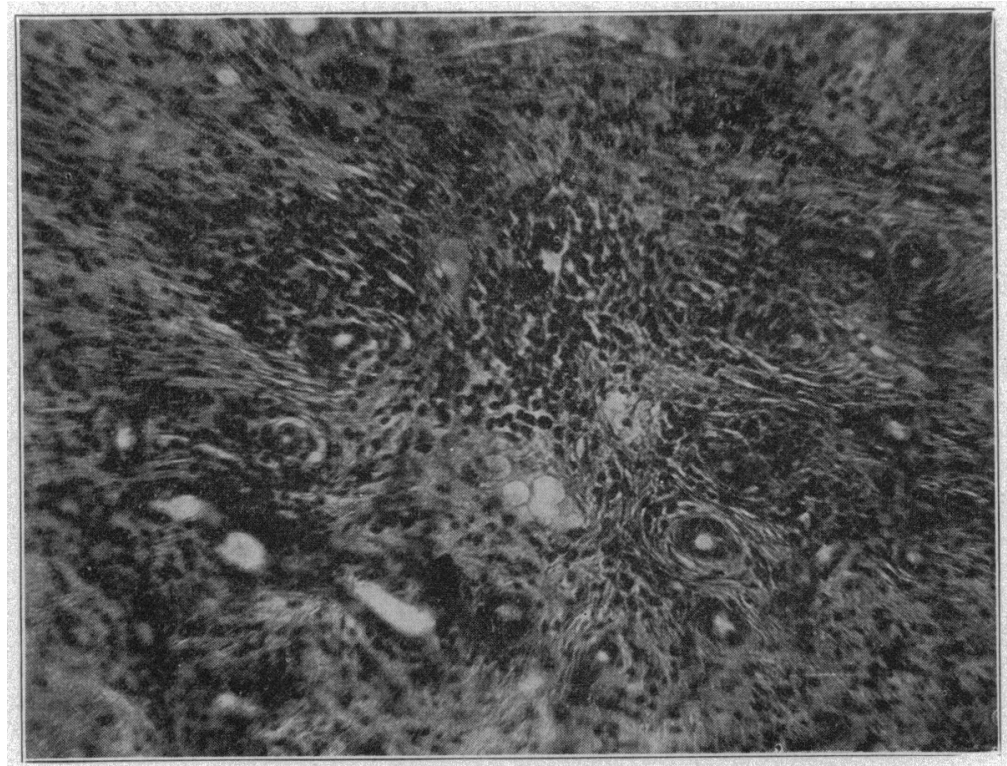

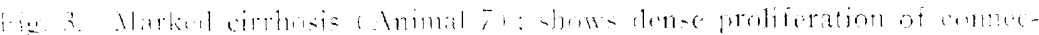

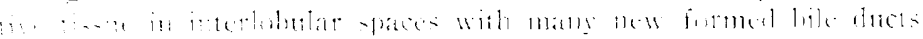


spaces. Some ingrowth into the lobule had taken place, but was not particularly far advanced. More or less increase of the intralobular connective tissue was also observed. The cells of the liver parenchyma showed pretty much throughout a moderate degree of albuminoid degeneration. Occasionally the central part of the lobule and in one place a whole lobule had undergone a more severe change, but not far enough to be called a true necrosis. With the higher power of the microscope the protoplasm of the cells has the lattice-work arrangement of threads as described previously. These threads where they crossed one another seemed to be sort of bunched up in a way similar to the nodal points in fibrin fibers. The protoplasm of the cells had a tendency to gather at the periphery of the cell along the cell membrane, and these threads intervened across the more central portion. The nuclei stained rather irregularly, having somewhat of a similar thread-like appearance of its chromatin. Karyokinetic figures were rarely observed, but a good many cells were seen

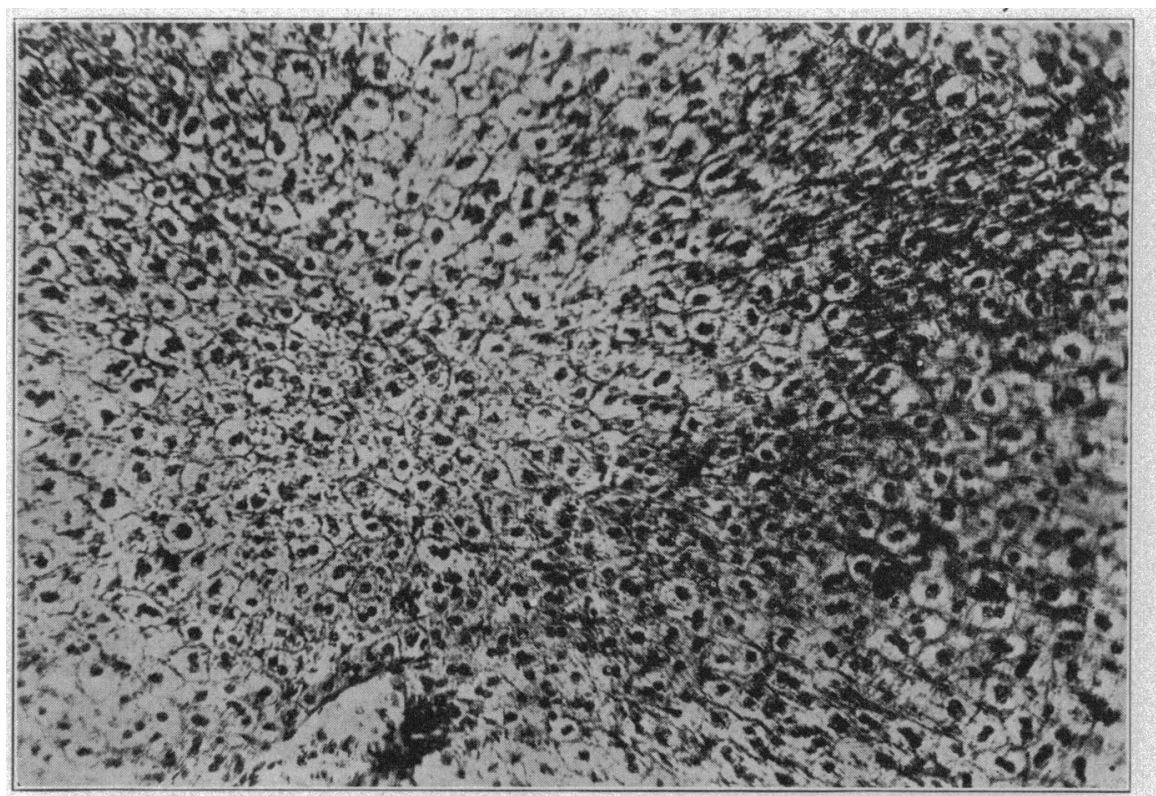

Fig. 4.-Complete parenchymatous degeneration with vacuolation (Animal 12). Nuclei appear broken up or have entirely disappeared.

with double nuclei. In some cells the nucleus was apparently lost, yet the protoplasm had the characteristic appearance already noted. An occasional cell was vacuolated, but nothing could be determined as to the contents of the same. Once in awhile a cell or a group of cells would stain more brightly than the others. As some of these had double nuclei, I took them to be regenerated or regenerating cells. Very rarely in the protoplasm of a cell could be made out a portion, really one of these nodal masses mentioned before, that took a brighter stain with eosin than the others. This may be the beginning of that hyaline skein-like degeneration that Mallory believes to be pathognomonic of alcoholic cirrhosis.

The intralobular blood capillaries were dilated and their walls could be fairly well made out. The endothelium of these as well as that of the lymph spaces in the portal regions was actively proliferating. 
Experiment 5.-Another animal was treated in the same way for four months, but at the end of the third month was inoctulated with 0.5 c.c. of a botillon culture of $B$. coli in the ear vein. Histologically the liver shows a beginning of cirrhosis but much less than the last. The bile ducts have not yet undergone any change, thus showing that bile-duct proliferation is a later process than the proliferation of connective tissue. The colon bacilli seemed to have no influence, thus acting contrary to the results obtained with it in chloroform necrosis.

Since this report was made another series of experiments have been carried out all on rabbits. In all, twelve animals have been fed alcohol in same dosage as in the first experiment. Six other rabbits, four from same litters and two from other litters, have been saved for controls. In brief these experiments resulted as follows :

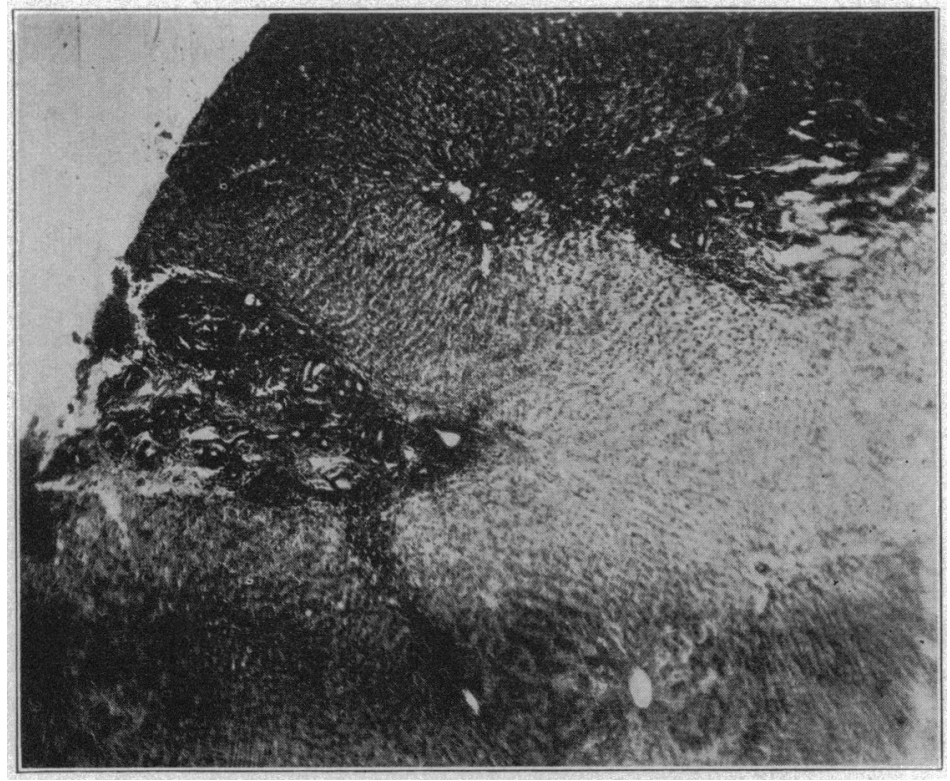

Fig. 5.-Extensive cirrhosis (Experiment 4); the interlobular connective tissue proliferation is well marked, but new formation of bile ducts is the most prominent feature.

Animal 1--Lived eight months. Liver shows no gross changes but microscopically one sees areas of degeneration, particularly in the periphery of the lobules. but in some areas extending in as far as the central vein. In one or two lobules there seems to be complete necrosis of cell protoplasm with vacuolation. The interlobular spaces are filled with proliferated connective tissue, which is commencing to invade the periphery of the lobules.

Animal 2.-Lived five months. Examination of liver showed passive congestion with some central necrosis. All the trabeculae seemed to be widely separated. There is some slight connective tissue increase in the interlobular spaces.

Animal 3.-Lived four months. Liver showed nothing except some fatty degencration. 
Animal 4.--Lived three weeks. Liver showed no change.

Inimals 5 and 6 were controls. One lived nearly a rear and thon died from pnemmonia. Liver showed no lesions. The second control is still living after thirteen months.

Animal 7 lived about ten months. Shows a marked cirrhosis.

The interlobular spaces throughout show very marked proliferation of connective tissue which is crowding in on the lobules, very profusely invading the parenchyma cells, which are more or less degenerated.

Animal 8 lived eight months. Showed a moderate degree of cirrhotic changes about half way between that of Inimals 1 and 7 .

Animal 9.-Control. Lived eleven months and then was killed by a dog that broke into the pen. Showed no liver lesions.

Animal 10.-Lired six months: showed marked beginning cirrhosis.

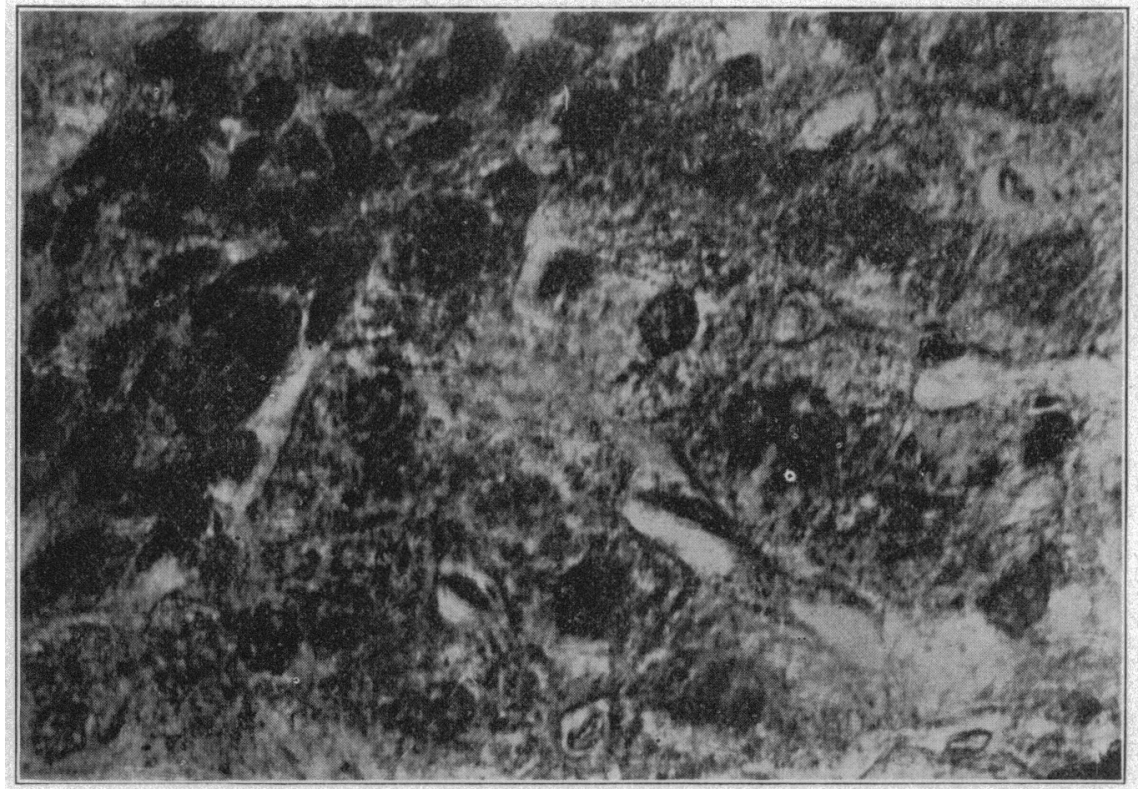

Fig. 6.---High power of liver parenchyma from same slide as Figure 5. Shows the skein-like formation of protoplasm with masses undergoing hyaline degeneration.

Animal 11.-Lived nine months; showed considerable connective tissue reaction. A rather marked cirrhosis with considerable bile duct proliferation. A good deal of parenchymatous tissue seems to have disappeared and to have been replaced by connective tissue. The newly-formed bile ducts can be seen running in the midst of this dense fibrous tissue.

Animal 12.-Animal killed after about twelve months on account of a severe long-stanciing torticollis. After nine months, the dose of alcohol was doubled. After two months more it was again doubled. Necropsy showed a pale, soft, enlarged liver. Nicroscopically, the cells are completely degenerated. Nothing remains but a vacuolated ccll with a broken up nucleus. In many instances the nucleus had disappeared.

Animal 13.--Lived ten months. Itad to be killed, as overgrowth of lower teeth resulting from broken upper ones prevented animal from eating. Liver 
showed enormously enlarged blood vessels and capillaries and quite a marked cirrhosis that appeared to be originating entirely from the blood vessels and in many places it was somewhat of the nature of an adventitial sclerosis.

The rest of the animals and controls are still alive. It is interesting to note that almost all the young born of females treated with alcohol were killed by the mother while those from the controls lived. From the work of previous writers, as well as from this work, it appears that the cirrhotic change is entirely a reparative process stimulated by injury to the liver ceils. The injury of the cell is manifested by albuminoid and fatty degeneration, but also particularly by vacuolation. At the same time there seems to be a gathering of the protoplasm irto the skein formation previously mentioned, where it appears to be

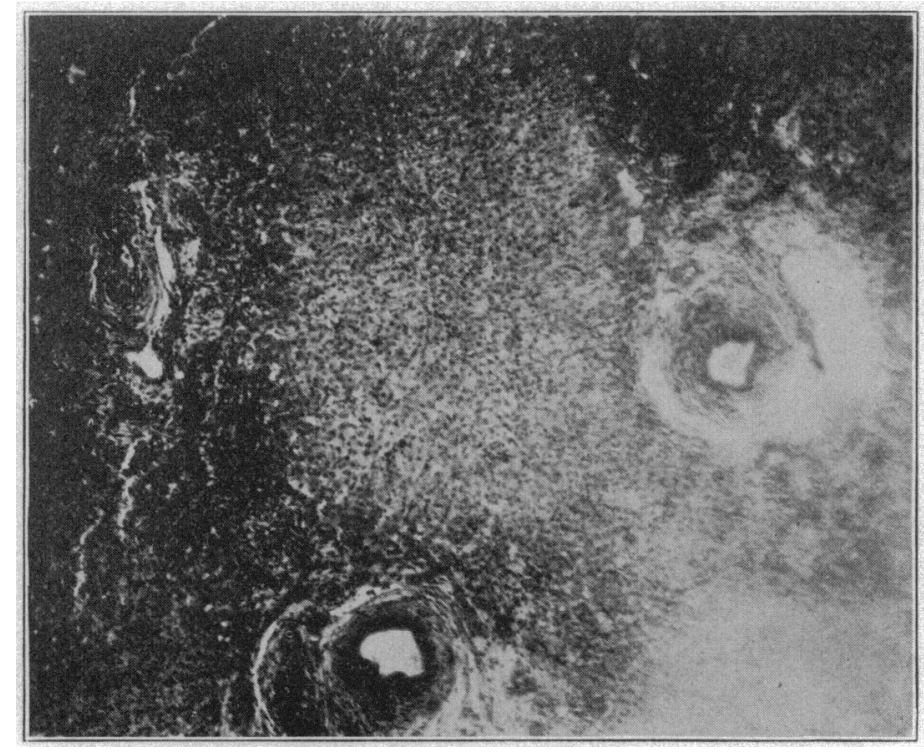

Fig. 7.--Showing a very early cirrhosis. The new formed connective tissue is seen proliferating from the region of bile ducts. Animal 10.

taking on a hyaline appearance very much like that which Mallory nentions as the diagnostic sign of alcohol degeneration. In all cases active regeneration of liver cells can be observed.

Some observers have claimed that spontaneous cirrhosis of the liver is a common condition in rabbits. This question has been fully considered in a previous contribution. ${ }^{31}$ The evidence presented in this contribution was briefly as follows:

Nearly three hundred rabbits had been necropsied as a routine laboratory procedure, and these were used as controls for the foregoing experiments with alcohol. No evidence of cirrhosis of the liver was fornd except in one case, in which the common bile duct was 
experimentally ligated, in one case of experimental pyemia, in one case of experimental chloroform intoxication, in three cases in which the rabbits died as a result of spontaneous pyogenic infection, and finally, in one case of infection with Coccidia oviforme. These animals were of the same strains as the ones used in the alcohol experiments together with many other strains, thus giving as fair a control as would be possible for one to find. As a result there has been no evidence found of spontaneous cirrhosis of the liver. The evidence brought forward by others is of interest, but I believe that a more careful examination would have shown evidence of infection of some sort as the source of the connective tissue proliferation.

In conclusion, it seems that when alcohol is given for a long period there follows degeneration of the liver cells, which in a large proportion of cases is followed by connective tissue proliferation. Whether any other process comes in to help is uncertain; nevertheless it remains pretty well proved that a cirrhosis can be obtained from alcohol in cases in which no other factor is apparent. 